\title{
GREEN? COVERED BOND? GREEN COVERED BOND!
}

\author{
Gyula László Nagy - Rita Bozzai - Illés Tóth - Zsombor Incze ${ }^{1}$
}

\begin{abstract}
In our study, we deal with the topic of green covered bonds with respect to regulators, directives and investors. We examine the difference between green covered bonds and traditional "brown" covered bonds and the reason why the explosion in the global green bond market was followed by a less dynamic boom and with a delay in the green covered bond market. We establish that, in the absence of special legal background, green covered bonds are not clearly separated from brown covered bonds due to the joint collateral pool and the pari passu principle. We also note that although there are pricing differences ("greenium") in many green bond sub-markets, there is currently no evidence of this in the green covered bond sub-market.
\end{abstract}

JEL codes: G18, Q59, G21

Keywords: covered bond, green covered bond, green bonds, covered bond regulation

\section{GREEN FINANCING, GREEN COVERED BOND}

Climate change, sustainability, environmental risks, global warming and the prevention of the extinction of species have been some of the biggest challenges over the past few years. Although no perfect international agreement and cooperation have been evolved to tackle the problem, international and local initiatives with this objective have become significantly stronger recently. In order to reduce the ecological footprint the international institutions and governments have pinned the conscious and accountable acting to their flags; the banking sector and the capital markets are no exceptions. Covered bonds as special strictly regulated subtypes of bonds may play a key role in the development of green financing. Cur-

1 Gyula László Nagy, CEO, Takarék Jelzálogbank Nyrt. E-mail: nagy.gyulalaszlo@takarek.hu. Rita Bozzai, Senior Consultant, Capital Market Department, Takarék Jelzálogbank Nyrt. E-mail: bozzai.rita@takarek.hu.

Illés Tóth, Director, Capital Market Department, Takarék Jelzálogbank Nyrt. E-mail: toth.illes@ takarek.hu.

Zsombor Incze, Project Manager, Takarék Jelzálogbank Nyrt. E-mail: incze.zsombor@takarek.hu. 
rently, in Hungary, there are 5 mortgage banks, four of which carry out so-called "refinancing" activity. The latter means that the refinancing mortgage banks do not directly finance the final consumer of the loan by transforming capital market funds, but rather fund those commercial banks which provide mortgage loans. Nagy et al. (2020) have conducted a thorough analysis of these operational models, clearly differentiating between the refinancing and the originating mortgage banks.

The main reason for writing this article was that green bonds appeared in Hungary and at the end of 2020, the preparation of the issue of green covered bonds was put on the agenda, as well. The preparatory work started with the active participation of the National Bank of Hungary and the Hungarian Banking Association. The authors of this article would like to contribute to this work in the hope that Hungarian mortgage banks will join Poland on the map of green covered bond issuers in the CEE region in 2021.

According to the data in the ECBC Covered Bond Factbook 2020 (Kullig et al., (2020), the annual publication by the ECBC (European Covered Bond Council), the total volume of outstanding covered bonds reached the volume of EUR 2.5 thousand billion in 2019 (Stöcker-Costa, 2020). In the light of this, the 250-year success story of the covered bond as the least risky (sometimes less risky than government securities) investment tool is still uninterrupted. In 2019, 329 issuers were registered, which has been the highest number so far. When this article is being written, the figures from 2020 are still unknown.

In Hungary, green bonds and the related issuer standards were described in detail by Mihálovits et al. (2019), partly based on Mihálovits-Tapaszti (2018) the following:

- they should be "green", therefore they should finance investment projects with environmental objectives,

- they should be cheap, cheaper for the issuer than financing based on nongreen (hereinafter referred to as "brown") securities,

- they should ensure appropriate transparency regarding the actual "green effects" for investors in exchange for a higher (purchase) price.

In spite of the dynamic growth of green senior unsecured bonds recently, the first green covered bond, in volume of EUR 300 million, was issued by MünchenerHyp, a German mortgage bank, relatively late, in September 2014 (sustainabonds.com, 2014). The coverage of Covered bonds consists of loans provided for cooperative housing projects, which fulfilled not only the objective of sustainability, but also the social criterion. MünchenerHyp has been a regular covered bond issuer in the German market, however, it was the first covered bond for which a green rating company (oekom, 2014). Based on the above, in fact, the first covered bond that 
complied with the ESG criteria is linked to MünchenerHyp. At the same time, it is important to mention that, according to oekom (2014), in the case of this issue, the "social" label is emphasised, however, it is stressed that the importance of environmental criteria may increase in the future. $32 \%$ of the investors belongs to the so-called SRI (Sustainable and Responsible Investor) category. Most of them had not even bought any security from Münchener Hyp before, which means that Münchener Hyp was able to reach a new investorsby issuing this new instrument (sustainabonds.com, 2014).

However, the investment market links the first official classically green mortgagebacked bond to BerlinHyp, a German mortgage bank (Kidney, 2015). This bond was issued in May 2015. As opposed to MünchenerHyp's ESG covered bond of EUR 300 million, it came out in "benchmark" size, worth EUR 500 million. Its four-time oversubscription shows the great interest of investors.

Despite the fact that the legal and security system of the covered bond (Pfandbrief in German) is based on a 250-year-long tradition, the issuer had to face new challenges owing to ensuring the appropriate green rating required for the coverage behind the covered bond and reaching the appropriate size. In Germany, commercial real estate is typically involved to cover covered bonds. However the "green" commercial real estate portfolio needed for the issue of covered bonds in volume of EUR 500 million was selected from German and international (French, English, Dutch and Polish) commercial real estate (Kidney, 2015). In this case, the portfolio was rated green by international rating company Oekom, as well. Based on the rating, the issue complies with the Green Bond Principles standard (oekom, 2015). Following the issue of the two German green covered bonds, new participants appeared in the market. However, the first mortgage bond covered exclusively by a residential real estate portfolio was issued only in 2018, as the establishment of the selection criteria based on an energy performance certificate or the year of building as well as the availability of such criteria required development (Schuller et al., 2020).

In 2020, the amount of outstanding green covered bonds still did not reach $1 \%$ of the total amount of outstanding covered bonds. This amount is low even today, which is all the more surprising, as in terms of the distribution of green financing by use, the share of energy efficient buildings takes a stable second place to the energy sector regarding the amounts used (Jones, 2020).

$84 \%$ of the green covered bonds issued until now are covered by real estate and $16 \%$ of them are provincial/municipal (public) bonds (Schuller et al., 2020). In the first half of 2020, the cumulated value of covered bonds serving sustainability objectives (including the green covered bond stock) amounted to EUR 21 billion, which was shared by 10 countries, as Figure 1 illustrates (Schuller et al., 2020). 
Figure 1

Distribution of sustainable covered bond stocks by issuing country

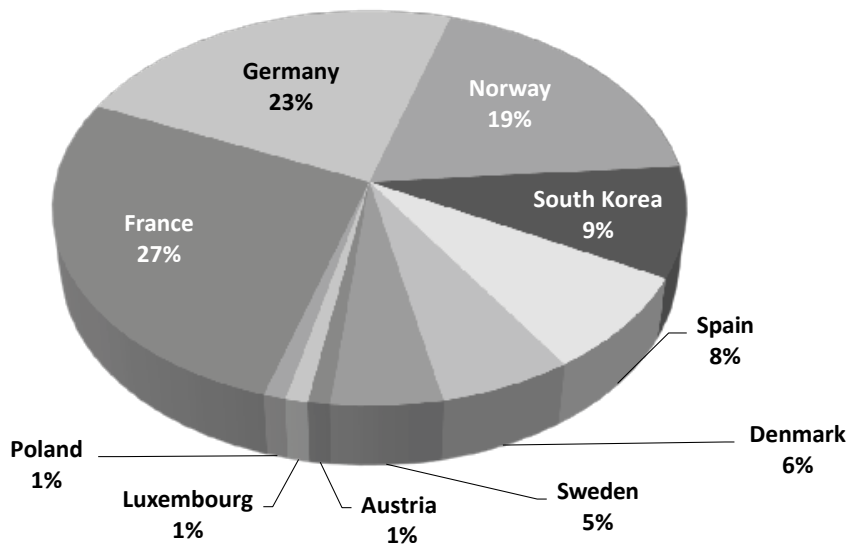

Source: ECBC FactBook 2020, edited by the author of this article

By the end of 2020, the green bond market arrived at an important milestone of its success story, which started in 2007. According to the database of the Climate Bond Initiative, the total volume of cumulated green debt instruments exceeded the value of USD 1 trillion. Institutions from 76 countries and further supranational organisations have contributed to the growth since 2007 (Jones, 2020).

As far as the use of green bonds is concerned, the energy sector leads the ranking with $35 \%$, followed by the sector of low emission (energy efficient) buildings with $26 \%$ and transportation with $19 \%$. Water management is ranked fourth with $10 \%$.

\section{GREEN ASPECTS OF THE REGULATORY BACKGROUND OF COVERED BONDS}

Bond, covered bond, mortgage bond, green lending, green securities: although they are more or less well-known terms individually, there is legitimate demand for placing 'green covered bond', the focus of our article, appropriately in the national and European regulatory environment in force and defining the investors' rights attached to this security type. Before providing a detailed overview of the terms above, it is important to mention that there are significant similarities between non-green and green covered bonds, while the green nature - a special lending target - opens up a new dimension for an already known asset class. 


\subsection{Identities}

\subsubsection{Regulation, legal background}

In most European countries, there is no difference between green and non-green covered bonds in terms of regulation. The only exception is Luxembourg, with which we will deal in detail later.

The security of covered bonds, or, from another point of view, their lower risk level compared to other asset classes, is underpinned by the fact the national regulation of covered bonds (if it exists) has been very detailed and thorough for centuries, which account for their security even in the most dramatic banking and financial crises throughout the 250-year history of covered bonds. In many cases, international credit rating agencies (S\&P, 2019a) give 3-4-6 grades higher ratings for the security ensured by the strict legal background than the issuer banks or the relevant country (sovereign rating). For example, in the case of Komercni Banka (Kunze, 2021), S\&P's rating was 6 grades higher than the sovereign rating. In Hungary, mortgage lending is regulated by Act XXX of 1997 on Mortgage Loan Companies and on Mortgage Bonds, however, in 2019, the Directive (EU) of the European Parliament and of the Council on covered bonds (EPC, 2019), which contains EU-level rules and whose domestic implementation is already in progress. Nagy et al. (2020) conducted a detailed analysis of the existing and new regulations from the point of view of refinancing mortgage banks, i.e. the most common national operating model.

From the regulation point of view, the green covered bonds are primarily covered bonds, and only secondarily instruments financing a green lending target. As they are (green) covered bonds, the same rules apply to their issue as to that of brown covered bonds. Without aiming to give an exhaustive list or prioritising, considering the investors' perspectives, the most important rules include the following:

i) Only a specialised mortgage credit institution carrying out limited activity shall be entitled to issue covered bonds (Section 11 (1) of Act XXX of 1997 on Mortgage Loan Companies and on Mortgage Bonds).

ii) As opposed to the all-time, unsecured, non-subordinated liabilities of the issuer, the liabilities arising from (green or non-green) covered bonds are on at par with each other in the course of the Issuer's liquidation or the enforcement proceedings launched against the Issuer (pari passu principle).

iii) In the course of the liquidation or enforcement proceedings, covered bonds do not accelerate automatically (bankruptcy remoteness principle) and, in the case of mortgage credit institutions, the ordinary coverage and the substi- 
tute coverage registered in the coverage register as well as certain liquid assets shall be used only for the fulfilment of liabilities towards covered bond owners, with regard to the fact that such (green, non-green) liabilities are not included in the property to be liquidated (Sections 20 and 21 of Act XXX of 1997 on Mortgage Loan Companies and on Mortgage Bonds).

iv) Mortgage credit institutes shall be entitled to issue covered bonds only if the value of credit institution's coverage exceeds the amount of the still non-repaid (outstanding) nominal value of the all-time (green and non-green) covered bonds and their interest. (Section 4 (1) of Act XXX of 1997 on Mortgage Loan Companies and on Mortgage Bonds). The aforementioned coverage appears in a single coverage pool. In this case, the double coverage principle also applies. Therefore, the investors shall have the right to enforce their claims against the issuer of the green/non-green covered bonds as well as the green and/or non-green assets involved in the coverage. Act XXX of 1997 on Mortgage Loan Companies and on Mortgage Bonds does not distinguish the subtypes of the issued covered bonds.

\subsubsection{A single coverage pool}

Similarly to the systems of other European countries, the Hungarian mortgage banking system knows only a single cover pool (pool). This fundamental thesis is not modified by the new EU Directive (EPC, 2019) either. Consequently, in Hungary there is no and is not expected to be any dedicated pool for residential mortgage loans, corporate mortgage loans or for local governments and other loan debtors. Similarly, there is no pool is dedicated to mortgage loans with green lending targets, irrespective of the fact whether their loan debtors belong to any of the above-mentioned groups.

In accordance with the law, the issuers of covered bonds shall have coverage behind their entire portfolio of (green and non-green) covered bonds. Consequently it applies to green covered bonds, as well, however, at the moment, no law prescribes that the underlying coverage shall be green.

In their Green Covered Bond Framework, the issuers of green covered bonds publicly undertake to spend the funds deriving from the sale of green covered bonds on (re)financing green loans. As a result, green covered bonds are covered by green coverage. If, contrary to the promise of the issuer, the coverage behind the green mortgage bond series is not green, the issuer does not infringe the law, as currently, no law is applicable to this case. In the absence of such a law, if the existence of all the legally prescribed (green and brown) coverage can be proven, neither the temporary or permanent lack of green coverage within the pool, nor the non-performance of lending targets entails legal sanctions. 
Due to the single pool and the pari passu principle, investors should be aware of the fact the coverage which significantly reduces their risks in a proven manner refers to the total amount of coverage. Based on the above, the existence of coverage shall be uniformly interpreted as coverage of the entire pool. The investors who bought green covered bonds and the investors who bought non-green covered bonds are covered by the same pool. In view of the above, investors in green covered bonds can only expect their investments to be allocated to green financing. Green coverage behind their investments cannot be expected, as the legal framework of this does not exist based on Act XXX of 1997 on Mortgage Loan Companies and on Mortgage Bonds.

In spite of the absence of a legal framework, it is crucial that mortgage banks distinguish between green and non-green mortgage loans within their pools and fulfil their commitments in the Green Covered Bond Framework.

\section{Figure 2}

The schematic balance sheet structure of the "brown" and "green" cover pools of mortgage banks
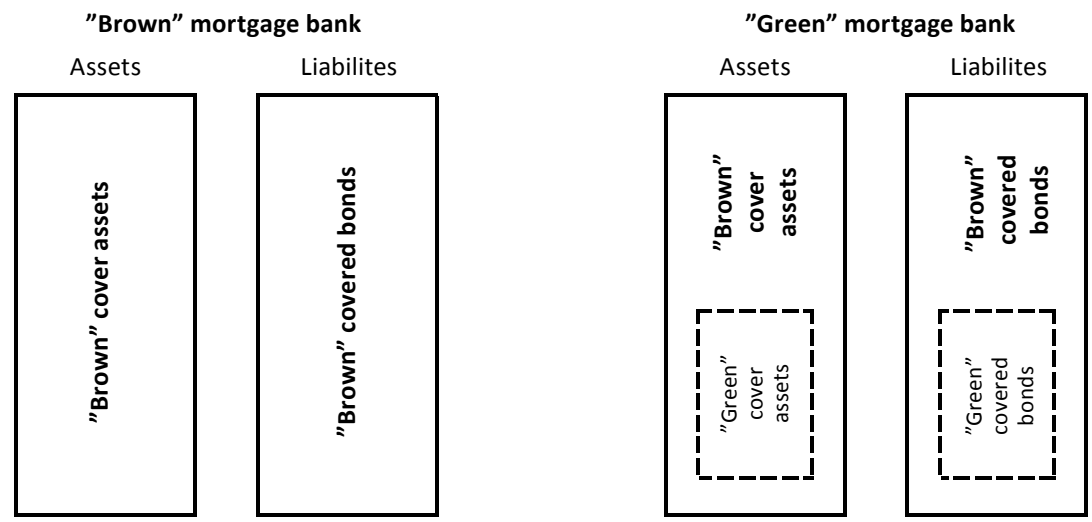

Source: the author of this article

International green standards contain several definitions of "green" (GBP, CBS), however, such definitions only partly cover the requirements related to the characteristics of the operation of mortgage banks. In the case of covered bonds, in order to receive a green mark, it is not enough if the amounts deriving from the issuance are spent exclusively on financing green targets, as, in our view, due to the basic characteristic of operation (disbursement of covered loans only), real estate coverage behind the covered bonds, or, in other words the greenness of the cover assets (collateral assets) can be expected. Only the coexistence of these 
requirements can prove that the target of the mortgage loan and the consequence of its achievement will have a positive effect on the environment. The lending target may be the real estate provided as collateral itself. In this case, the lending target can be defined based on the energy efficiency of the real estate. Where this is not the case, the "green" character of the lending target shall be demonstrated in a different way.

As for mortgage loans to be disbursed in the future, internal classification is simpler, as a lot of relevant new information can be collected from the loan debtor. At the same time, in the case of mortgage loans already disbursed prior to the appearance of green targets, it is more difficult to classify the loans, as domestic banks had not been prepared for obtaining any other information e.g. data needed for energy efficiency rating (energy performance certification) other than the information that had been usual in mortgage lending over the past two decades from the potential loan debtor. However, it needs to be taken into account that in the initial phase of green programmes, only those loans whose positive effect on the environment can be proven by the bank disbursing the loan - a mortgage bank or the partner bank to be refinanced - can be marked as green within the pool. Such proof may be the aforementioned energy performance certification or any other calculation which verifies the protection of the environment.

\subsection{Differences: purposes of use, monitoring}

\subsubsection{Green objectives}

When talking about green targets, the green (mortgage) lending target and the target of using the revenue deriving from the sale of green covered bonds may merge into on another. At the same time, the two targets are closely related. Regarding the definitions on the basis of which the specified targets can be considered to be green targets, different international standards and principles are available and can be complied with, however, there are no valid and European-level laws at the moment.

The fundamental principle of a green lending target is that it should somehow have a positive effect on the environment. First of all, the Issuer should have its own green vision, undertake its implementation and prove the fulfilment of its commitment convincingly towards the investor. Basically, this vision should be based on the extended sustainability concepts published by the parent companies of mortgage banks, taking into account the special features of the mortgage bank as a specialised credit institution. The Green Framework System mandatorily published by the mortgage bank provides more information about the aforementioned targets and principles. 
According to international experience, the use of proceeds from the issue of green covered bonds is included in the issue documentation, primarily in the Final Terms and Conditions. In the Final Terms and Conditions, the issuer explains in detail that it intends to spend the incoming amount partly or entirely on financing/refinancing new or already existing green projects and publishes the Green Covered Bond Framework, which summarises the principles.

\subsubsection{Green asset supervisor?}

An independent asset supervisor certifies the availability of the coverage (irrespective of its green or non-green character) in accordance with Act XXX of 1997 on Mortgage Loan Companies and on Mortgage Bonds. However, the "green" character of the coverage is not

checked by the independent asset supervisor, but, in accordance with the issuer's regulation typically by the Green Covered Bond Committee, based on the issuer's Green Covered Bond Framework (The Green Covered Bond Committee is usually responsible for the maintenance of this Framework). Some examples include the framework systems of the following banks: the PKO Bank Hypoteczny (PKOBH, 2019), the mBank Hypoteczny (mBank, 2020), the OP-Asuntoluottopankki Oyj (OPMB, 2020), the DNB Boligkreditt (DNBB, 2020) or the Berlin Hyp (BerlinHyp, 2020).

In view of the above, the basic document of green covered bond issuance is the Green Covered Bond Framework. Its compliance is usually proven by a SecondParty Opinion or, regarding compliance with specific standards, a certificate. If the issuer holds such an opinion and/or a certificate, the issued bonds can be labelled as "green".

In view of the above, it is not an external rating company's responsibility to rate a covered bond's coverage as green. The issuer itself shall be in charge of the rating based on a framework system qualified as green (Green Covered Bond Framework).

\subsubsection{Sustainability factors may further improve the security of investors in green covered bonds}

In the case of ESG covered bonds, particularly green covered bonds, the biggest challenge investors have to face is to get acquainted with the green content of the underlying asset pool and to interpret the effects of the ESG/green factors on the credit quality of the underlying asset pool. Nowadays, in the market (as opposed to the market of classic credit rating agencies), there are numerous green rating companies which rate the green framework of individual issuers. However, the 
preference systems behind specific ratings are not standardised, therefore it is difficult to compare them. It is not surprising that, at the present "early" stage of development of green covered bonds, both the issuers and the investors "expect some help" primarily from credit rating agencies, but, not surprisingly, currently, credit rating agencies do not really agree with the excessive upgrading expectations related to ESG securities in terms of the effects of ESG factors on credit ratings.

As far as the view of credit rating agencies is concerned, the following approach seems to be general: when examining the effect of ESG factors on credit rating, including the rating of underlying asset pools, it has to be considered whether these sustainability factors improve the liquidity position of the issuer (its access to funding resources), the quality and profitability of the loan portfolio (Marty-Hunter, 2020; S\&P, 2018). In line with the increasing frequency of issues, the available statistical sample consisting of more and more elements will provide an increasingly reliable overview of the green risk and spread in the case of the individual issuers, however, the general, market-level calculation of these will remain a serious challenge for investors in the future, owing to differences between green and non-green covered bonds. In our view, in the case of green covered bonds, the factor that, according to the analysis of Billio et al. (2020), energy efficient loans have lower risk of bankruptcy, therefore the green real estate collateral behind the loans involved in the cover pool represent a higher and more stable mortgage value in the long run. Of course, the question is when the market and the credit rating agencies consider this assumption as proven and recognise it the form of (higher) rating and (lower) spread.

The relative pricing of the risk profile of underlying asset pools are supported by both the scaled credit rating systems of the mortgage bonds issued by the individual issuers and the transparency reports on the available underlying asset pools on which they are based, while no uniformly scaled comparative systems concerning the green quality of the green coverage behind green lending targets, green covered bonds and real estate collaterals exist, or, at least initially, only limited information will be available for market participants. On the other hand, in our opinion, based on Schütze (2020), investors should have the opportunity to compare the climate risks of their individual investments as a reaction to climate change. 


\section{GREEN COVERED BOND DIRECTIVES}

Mortgage covered bonds, as special, strictly regulated bonds, basically receive a "green" rating in accordance with the principles applicable to bonds. In Hungary, pursuant to Act XXX of 1997 on Mortgage Loan Companies and on Mortgage Bonds, mortgage loans provided by mortgage banks shall always be covered by mortgages on real estate, therefore, the underlying asset pool of covered bonds includes loans covered by real estate only. This practice differs from the practices applied in many other European countries, where covered bonds can be covered by ships, aircrafts or loans provided to the state or local governments; typically, the latter possibility exists in the case of Germany, Italy and Poland. However, there are also examples for narrower terms similar to those in Hungary, for example in Switzerland and the Czech Republic (ECBC, 2021). The scope of activities which can be financed is relevant, because it fundamentally determines the possibilities of green rating.

Currently, two global reference documents are used for the definition and backtesting of the "green" character of green bond issues. One of these documents is the Green Bond Principles published by the International Capital Markets Association (ICMA, 2018), while the other one is the Climate Bond Standard (CBI, 2019) maintained by the Climate Bond Initiative as well as its summary entitled CBI Taxonomy (CBI, 2020). The Green Bond Standard of the EU (EU, (2021) is an ongoing project based on the EU's taxonomy of sustainable activities (EU, 2020), with the aim of enabling the European Commission to lay down the principles of green rating of green bonds issued in the EU after comprehensive consultation.

In Hungarian professional literature, the GBP, CBS and EU principles related to green bonds have been compared by several authors (Mihálovits et al., 2019; Mihálovits-Tapaszti, 2018), while Dobránszky-Bartus-Krenchel (2020) focused explicitly on the green investment taxonomy of the EU (EU, 2020) in detail. In addition, useful conclusions can be drawn from the green covered bond principles (VDP, 2019) valid in Germany, as well.

As our article focuses expressly on green covered bonds, we do not aim to describe the basic requirements for the issue of green (unsecured) bonds arising from the aforementioned standards. Only the main characteristics will be highlighted instead.

The Hungarian State complied with GBP in their first euro issue, receiving a medium level on a three-grade scale (light, medium, dark green) from CICERO (CICERO, 2020). In the domestic corporate market, only green uncovered bonds had appeared before, with considerable support by the central bank. In 2020, in the framework of the National Bank of Hungary's Bond Funding for Growth Scheme, the first domestic green corporate bond was issued. CPI Hungary put its 
green securities of 10 -year maturity with a $2.25 \%$ coupon of a total nominal value of HUF 30 billion on the market, receiving a Baa2 rating from Moody's (MNB, 202ob).

The question of stricter or less severe requirements has arisen not only in the course of the investigations of national lawmakers and market participants, but international concerns have also been expressed mainly because of the possible appearance of greenwashing, the most important risk of green securities. The variety of simultaneously operating stricter and less severe standards may deceive investors and make it more difficult to decide which standard would be more compliant with their internal policy. This dilemma was explained by the representative of the European Central Bank in the round table debate of the online International Conference on Green Finance (MNB, 2020a) organised by the National Bank of Hungary jointly with EBRD on 12 October 2020, urging transparent comparability, the establishment of common language and the provision of guidance for investors. According to the ECB's representative, different international labels, recommendations issued by state institutions and central banks are useful reference points.

\subsection{Green Bond Principles (GBP)}

GBP consists of four main components, the regulation of which is of critical importance on the part of the issuer. Their existence is usually examined by rating agencies. The components: use of proceeds from the sale of bonds, selection of loans in line with the climate objectives, management and allocation of proceeds from the sale of bonds and preparation of reports on the allocation and the environmental impacts. In total, GBP lists 10 project categories which can be financed on GBP basis. From these categories, energy efficiency, agriculture (under certain conditions) and green buildings may be subject to Act XXX of 1997 on Mortgage Loan Companies and on Mortgage Bonds.

According to GBP's recommendation, as already mentioned, issuers should apply a "Second Party Opinion" (SPO) to verify compliance with the criteria and have it rated. Green rating differs from credit rating even if credit rating examined environmental risks in a given case.

A specific covered bond, the Green Covered Bond Framework constituting the basis of the issue of multiple green mortgage bonds or the use of the amount deriving from the sale of bonds can be rated. 


\subsection{Climate Bond Initiative Standard (CBI)}

CBI (2020), whose significant part is based on GBP, classifies the individual assets funded into eight categories: energy, transportation, water, buildings, land use and marine resources, industry, waste and pollution control, information and communication technology. From the categories above, buildings and land assets are closest to the operation of domestic mortgage banks.

Concerning buildings, basically, residential properties and commercial properties fit into the category of financeable assets. In the case of such buildings, the CBI expects them to belong to the best $15 \%$ regarding energy efficiency under local market conditions or significantly reduce their $\mathrm{CO}_{2}$ emission due to renovation. As regards Hungary, CBI published its country-specific expectations (CBI, 2021) regarding residential property in January 2021. Based on these, real estate holding energy performance certificates issued after 1 January 2016 qualify as "green" covered bond coverage only if in the middle of the maturity of the issued bond, their specific primary energy consumption indicated on the certificate does not exceed the maximum energy consumption expected by CBI at the time. The expected volume of energy consumption was also published.

According to CBI's standard, the range of agricultural assets is wide, as from livestock to IT solutions supporting farm management, several solutions may be interpreted as green. However, pursuant to the narrower definitions laid down by Act XXX of 1997 on Mortgage Loan Companies and on Mortgage Bonds, three principal activities remain: financing of arable lands, forests and fishponds. Interestingly, the standard allows the financing of uncultivated lands used for the restoration of the natural ecosystem, as well, however, it is still uncertain whether such lands can be financed through a bank. Based on a summary by Hoyer (2017), it has been clear since the very beginning that the term "green" should not mean the financing of projects with otherwise inappropriate financial indicators.

\subsection{Additional principles of issue in Europe}

On 1 July 2018, Luxembourg established its own green covered bond regulation (LU (2018)). The completely new class of bonds, the conditions of which are stipulated by the law, aims to make the production of renewable energy more easily financeable. The principal achievement of this legislation is that is regulates the main components defined by the GBP standard, such as the intended use of the income deriving from the issue, selection and assessment of green projects, management of the revenues deriving from the issue and provision of information related to the acquisition of funds through green issue. 
The first issue was executed by NORD/LB Covered Bond Bank Luxembourg, a local bank of NordLB in accordance with the new rules in January 2020, issuing green covered bonds in a volume about EUR 300 million (NORD/LB, 2020).

However the Luxembourg regulation differs from the Hungarian rules. Within the issuing bank, a dedicated (separated) pool, which consists of loans financing the infrastructure of renewable energy production, covers green covered bonds (Zeidler-Bredholt, 2018; Kremer et al., 2018). Consequently, the financing of renewable energy production became securer due to the institution of dual recourse, which had basically been a unique feature of mortgage bond structures before.

Kremer et al. (2018) prepared a detailed summary of the Luxembourg regulation. A major difference between the regulation and Act XXX of 1997 on Mortgage Loan Companies and on Mortgage Bonds is that, in addition to mortgage on real estate, the Luxembourg regulation allows the pledging of movables or project shares as well as the consideration of right in them Moreover, the law enables the bank to "step in" ("step-in rights") in case the renewable energy project could not pay back the loan. In this context, "stepping in" means that the bank steps in the "substantial" contracts of the project to enable the continuation, sale or handover of the project. The range of "substantial" contracts is defined by the law.

\subsection{The green covered bond framework in Germany}

In 2019, VDP (Association of German Covered Bond Issuing Banks) published its green covered bond principles (VDP, 2019), the prerequisites for the use of the names "Green Pfandbrief” or "Grüne Pfandbrief".

"Pfandbrief" has been the recognised brand of the German covered bond all over the world for a long time. Therefore, the introduction of the band "Green Pfandbrief / Grüner Pfandbrief” in 2019 was a new milestone in the centuries old success story of Pfandbrief.

Main features:

- The conditions of issuance shall correspond to the conditions laid down by the applicable covered bond law (Pfandbrief Act) and the Green Bond Principles (GBP) in force at the time of issuance.

- The issuance resources shall be used only for financing/refinancing the "appropriate" (green) assets.

- The following green assets fulfil the criteria:

- in the case of newly built real estate, the strict energy efficiency category applying to new real estate in the country concerned shall be complied with 
- in the case of financing existing commercial real estate, within the given category, the real estate shall fall into the upper $15 \%$ of national real estate stock in terms of energy efficiency and shall also comply with different prevailing official rules

- In the case of existing residential real estate, one of the following requirements shall be fulfilled:

- A residential property's energy classification shall be " $\mathrm{B}$ ” or higher

- The energy consumption of the apartment shall not exceed $75 \mathrm{kwh} / \mathrm{m}^{2}$

- The project shall be included in the KFW energy efficient construction/ renovation programme

- The financed apartment shall belong to the upper $15 \%$ of the national housing stock in terms of energy efficiency

- In the case of renovation/reconstruction, the energy consumption features of the real estate shall be improved by at least 30\% compared to the period prior to renovation.

- In the pool of underlying assets, green assets shall always reach/exceed the amount of green resources.

- An external green rating agency shall be employed.

- Concerning the green bonds' portfolio, certain publication obligations shall be fulfilled.

\subsection{EU Taxonomy}

The EU Taxonomy Regulation (EU, 2020) aims to support the achievement of the EU's climate goals, providing, inter alia, a framework for environmentally conscious investors and market participants, being responsible for the green rating of investments.

Hay (2020) summarised the comprehensive criticism related to the EU Taxonomy Regulation. The draft became subject to crossfire right after its publication at the end of 2020. Professional circles concerned find certain rules too permissive, while others too strict.

The issuers of green covered bonds were unanimously shocked at the clause which, in the case of the purchase and aquisition of real estate, allows the set-off of only real estate belonging to the energy category " $\mathrm{A}$ " as green assets. Currently less than $1 \%$ of the European real estate stock would fulfil this strict requirement if the Taxonomy was applied, therefore most green mortgage bonds covered by real estate would lose the green rating. However, issuers still prefer the still valid 
$15 \%$ category (best in class) or, in other words, the currently accepted and applied principle according to which the real estate which belongs to the upper $15 \%$ of the real estate stock of a given country in terms of energy efficiency can be involved in the green covered bond pool as coverage.

\section{INVESTORS' MOTIVATION}

No Hungarian green covered bond has been issued so far, however, the green covered bond programme announced by the National Bank of Hungary (MNB, 2020c) motivates mortgage banks to launch the new instrument as soon as possible. On the other hand, issuers face several difficult dilemmas.

\subsection{Issuers' dilemma}

Hungarian mortgage lending, which has a more than 20-year-long history, is based on conservative regulation, therefore one of its basic principles is that the issue of covered bonds is preceded by mortgage lending, i.e. the collection of coverage. We have already established that, in the case of already disbursed mortgage loans, the lending target or the green character of the coverage shall be proven somehow subsequently. This requires the establishment of a generally accepted system of criteria, in which the existence of green conditions can be proven by exact metrics. Based on internationally accepted metrics, only a small percentage of the Hungarian mortgage loan stock can be considered as green.

Building of green coverage with new loans is probably a slow process, though, in the case of green securities, the size and liquidity of a given series is a fundamental point to consider for investors. To overcome this difficulty, in some countries certain issuers apply a method according to which the non-green pool is already available, however the green mortgage loans or those with a green lending target are involved only gradually behind the already issued green covered bond portfolio. . In such cases, in compliance with international standards, the issuer undertakes to allocate the incoming funds on financing green loans within a specified time and hold the funds, which have not been allocated to green loans, in money market instruments for the purpose of liquidity management at its sole discretion, preferring green assets or simply adhering to the coverage and margin requirements in the mortgage law of the country concerned. For example, the longest allocation period as of the issuance is 12 months in Finland (OP Mortgage Bank - OPMB, 2020) and 24 months in Poland (PKOBH, 2019; mBank, 2020). 
There are several examples for the stipulation of publication obligations related to the regulation of green covered bonds, as well. In many countries, an applied standard prescribes what kind of information and how often shall be provided to investors, e.g. about green coverage at the time of the issuance of the green covered bond. The Green Bond Principle (GBP) prescribes annual public data reporting obligation (ICMA, 2018). In many European countries banks apply the GBP, for example, the aforementioned Finnish OP Mortgage Bank (OPMB, 2020), the Polish mBank Hipoteczny (Sustainalytics, 202ob), the Luxembourg NordLB (Sustainalytics, 2019a) and the German BerlinHyp (ISS-ESG, 2020). Certain banks (PKO Bank Hypoteczny, DNB Boligkreditt, Nykredit), meeting the criteria for $\mathrm{CBI}$ qualification, but not forgetting the GBP, also opted for annual reports. (Sustainalytics, 2019b; 2020a; 2020c). Consequently, the annual reports are general. However, it is imaginable that in some countries, legislation or perhaps the documentation of the country's green trademark will include the prudential rules. It is not impossible either that publications related to green covered bonds will be integrated into the transparency reports requested by credit rating agencies (e.g. Moody's and S\&P), central banks (e.g. the National Bank of Hungary), due every quarter.

Green securities need green investors. Which circle of investors is hungry for green covered bonds? Based on the experience of a Slovenian participant representing issuers at the conference organised by the National Bank of Hungary MNB (2020a), in countries where there are still no serious traditions of green banking and capital market products, the issuers themselves have to prepare the investors and provide them with information to sell their green securities. This statement probably applies to domestic covered bond issuers even more.

Apart from the expected yield, investors always examine the liquidity of green securities, transparency and secondary market making. These market building elements increase investors' confidence.

\subsection{Questions related to the pricing and rating of green covered bonds}

The term "greenium" originates from anecdotes by issuers according to which, due to high oversubscription, bonds could be sold with a great price advantage in the course of the issuance of green bonds. Therefore, greenium refers to the price premium an investor is willing to pay for a green bond (Harrison et al., 2020).

Numerous international publications deal with this topic. Several analyses and studies try to prove the existence of greenium and quantify its scale, as, since the issue of the first climate-conscious bond in 2007 (Hoyer, 2017), a sufficient amount of securities have been issued in several asset classes. 
The majority of international research findings prove the existence of greenium, however, there are differences regarding its scale. As opposed to 20 basis points indicated in the early period of the green bond market (Preclaw-Bakshi, 2015), based on certain research findings ( $\mathrm{Lau}$ et al., 2020), the average negative green spread amounts to merely 1-2 basis points. At the same time, the volatility of the scale of the greenium indicated by means of statistical models does not necessarily follow the development of the green bond market as a trend. This kind of volatility rather derives from the set of conditions of the applied models and the differences between the methodologies of sampling (which focus on markets). Models based on the comparison of the spreads of green instruments and conventional non-green instruments with similar parameters, Zerbib (2017) and Larcker-Watts (2020) showed a low green bond spread, which was typically a few basis points below zero or around zero basis point. Lower greenium can typically evolve in certain sub-markets in terms of a certain issue volume, primary-secondary market or the foreign exchange of issuance (Wensaas-Wist, 2019; Partridge, 2019; Partridge-Medda, 2018).

In our view, the indicated moderate negative green spread can be interpreted in many ways, concerning investors' attitude to green bonds. Based on the simplest conclusion, investors are not willing to accept lower return even if the green use of the funding resources has been proven. According to a different approach, exclusively green-specific risks arising from green bonds (the risk of "greenwashing") set off the added value of green instruments (ensuring climate goals) for investors to a certain extent - in extreme cases, completely. At the same time, the latter is excluded by the research conducted by Larcker-Watts (2020), therefore, the minimal or non-existent difference in spread showed by research is not caused by greenwashing in the examined markets. Incidentally, they could not prove the existence of greenium at all, studying the municipal bond market of the United States.

From the issuers' point of view, not only the level of the available green cost of funds is important, but also the need that the lower issuance spread offsets the extra costs of fundraising, as opposed to the issue yield of non-green bonds. Consistent with reason, under market conditions, the aforementioned need of the issuer is satisfied if the investor recognises the existence of these cost components and their added value to the achievement of green goals. Although we believe that the issuers' aforementioned expectation is economically justifiable, issuers have great responsibility for making investors recognise the added value.

It can be shown that the absolute scale of the greenium is higher in those countries whose commitment to climate protection is stronger (Larson, 2018). However, it does not mean only transparency. As Ameli et al. (2020) established when examining insurance and pension fund investors, transparency itself is not enough. It 
is also important to take into account complex policy measures, market-pricing frameworks as well as structural barriers. Such a point to consider may be the appropriate regulation of publication. With the involvement of investors, they may be encouraged to get over incentives for short-term decisions.

Specifically, as regards green covered bonds, little research has dealt with topic so far, and they did not mention the presence of considerable greenium. In view of the above, rating, reporting and other "green" costs are borne by banks at the moment (Schuller et al., 2020; DZHYP, 2020).

On the whole, it is observable that greenium evolves in developed markets committed to climate protection, mainly related to asset classes in the case of which issuance starts originally from higher spreads, therefore there is more room for diverting the price based on non-financial considerations.

\subsection{The presence of the National Bank of Hungary is especially important for launching the Hungarian green covered bond market}

According to our expectations, as opposed to the issue of uncovered green bonds, raising green funds in the form of covered bonds in a single pool legislative environment based on a specialised credit institution system, such as the Hungarian system, may increase the security of green investors, however, only if the increase in the value of real estate involved in the underlying asset pool can be proven or the green mortgage loan itself carries lower risks. However, it is not easy to prove the existence of such conditions. Neither domestic, nor international guidelines exist in this respect. The coverage behind green covered bonds is certified by the asset supervisor, while the green character of coverage and the targets is verified by the Green Covered Bond Committee based on the Green Covered Bond Framework qualified as appropriate by the issuer of the SPO in accordance with standards. However, in our view, the issuer has to convince the investors (and the credit rating agencies) about the risk-mitigating characteristics of green coverage by presenting appropriately transparent indicators, such as about the fact that after the achievement of lending targets, the loan debtor's ability and willingness to pay increases. Standardisation would be very beneficial in this field, as well (S\&P, 2019b).

Transparency probably helps to persuade investors, but - especially in a "greening market" such as the Hungarian market - it is still not enough. Although Hungarian mortgage banks are already preparing for the issuance of a green covered bond, without the active collaboration of the National Bank of Hungary, the Hungarian green covered bond market would start only slowly and with difficulty. 
Based on previous experience, in the course of mortgage bond purchase programmes organised by the National Bank of Hungary, the average issue spreads compared to government bond benchmarks was lower than the average issue spreads in periods when the National Bank of Hungary's purchase programme did not exist.If the situation remains unchanged even in the course of the announced purchase programme $(\mathrm{MNB}, 2 \mathrm{O} 2 \mathrm{Oc})$, it will be difficult to determine the scale of greenium, as it will have to be separated from the usual effect of the presence of the National Bank of Hungary experienced so far.

However, the increasingly dominant presence of green real estate collateral behind underlying cover pools may gradually lead to upgrading in the case of mortgage bonds. At the same time, it is questionable whether it will make the pricing of green covered bonds more favourable or rather the financing by non-mortgage bonds more expensive. On the other hand, a possible upgrading trend related to sustainability factors may put bigger pressure on issuers and national lawmakers to increase and support the intensity of the involvement of green assets into underlying asset pools.

\section{CONCLUSION}

As we are practicing bankers, our article principally draws on analyses, reports available in the topic, since, regarding this special capital market product, scientific literature is still very scarce. The scarcity of available professional literature can be explained by the fact that the green covered bond is a new capital market instrument with great growth prospects.

With the promising collaboration of the National Bank of Hungary, green mortgage lending and the establishment of the green covered bond market have already started in Hungary. Any mortgage bank can launch its first green product in the market anytime, as no laws prohibit this move. A bank that is entitled to issue a covered bond is also entitled to issue a green covered bond, however, it should hold all the green accessories.

The most important of such accessories is the "double green protection" behind mortgage bonds, i.e. the fundamental thesis according to which not only the lending target, but also the underlying real estate coverage has to be green. It is this most fundamental difference that may expand the risk margin between green unsecured bonds and green covered bonds. Regarding the latter, it is a significant risk benefit that the criteria of covered bonds originally include strict monitoring and transparency. It applies to green covered bonds even more. The daily control of the pool will automatically include the constant monitoring of green coverage. 
As, in contrast with green bonds, the volume of outstanding green covered bonds is still much lower. In an already established and liquid covered bond market (e.g. in Germany), the presence of the greenium is still less common than in the larger green bond market with longer tradition. International credit rating agencies are still careful when judging the effect of sustainability factor on credit quality. However, it is expected that they will take sustainability aspects more into account in the future.

There are already studies proving the positive effect of green factors on credit quality by statistical surveys (Billio et al., 2020), however, individual issuers will have to support this assumption with their own internal risk models in the future. The first research findings in the topic are promising, therefore, it is expected that following the issuers, more and more investors will accept the claim according to which green covered bonds carry lower risks than their "non-green" counterparts.

Although Hungarian investors are already interested in investing into green covered bonds, it is still uncertain whether their confident expectations express their green commitment or the purchases announced by the National Bank of Hungary. One thing is sure, the anticipated demand by the National Bank of Hungary $(\mathrm{MNB}, 2 \mathrm{O} 2 \mathrm{Oc})$ counts a lot. Without the participation of the National Bank of Hungary, green "mortgage banking" would develop much more slowly. The long-term prospects of the domestic green covered bond market will be seriously determined by whether, in addition to the National Bank of Hungary, there will evolve a dedicated basis of green institutional investors.

At the time of closing our article, there are only assumptions about the end of the crisis caused by the COVID-19 virus, about when life will return to normal and when economic indicators will increase. More and more figures are being published about year 2020, reflecting severe economic recession and a still unexperienced increase in debt. The financial sector will probably undergo significant changes after the rearrangement anticipated from the second half of 2021.

However, it seems to be more certain that the advocates of climate protection were right. Today, the question is not about the existence of global warming or whether we should do anything. It is rather about how to achieve the goal of providing normal living conditions for future generations on our planet, as a result of "last minute" global actions. Consequently, investors are expected to significantly change their attitude so that we can achieve our sustainability goals.

The Hungarian green covered bond programme might provide considerable financial support for the modernisation of the domestic housing and real estate stock as well as for the achievement of sustainability goals. The green covered bond will not only make the palette of the already existing capital market prod- 
ucts more colourful, but it will also enable us to take some important steps towards the attainment of our sustainability goals.

\section{REFERENCES}

Ameli, N. et al. (2020): Climate finance and disclosure for institutional investors : why transparency is not enough. Climatic Change, 160, 565-589, https://doi.org/10.1007/s10584-019-02542-2.

BerlinHyp (2020): Green Bond Framework, Berlin. Available at https://www.berlinhyp.de/en/investors/green-bonds?file=files/media/corporate/investoren/green-bonds/green-bonds/greenbond-framework /en/2020-04-27-greenbondframework-en.pdf (downloaded: 22.01.2021).

Billio, M. et al. (2020): Final report on correlation analysis between energy efficiency and risk. https:// eedapp.energyefficientmortgages.eu/wp-content/uploads/2020/o8/EeDaPP_D57_27Aug20-1. pdf (downloaded: 05.01.2021).

CBI (2019): Climate Bonds Standard.

CBI (2020): Climate Bonds Taxonomy. https://www.climatebonds.net/standard/taxonomy (downloaded: 27.12.2020).

CICERO (2020): 'Second Opinion' on Hungary's Green Bond Framework, Oslo. https://cicero.oslo. no/file/1238/CICERO_Green_Hungary_SPO_25May2020.pdf (downloaded: 16.12.2020).

DNBB (2020): DNB Boligkreditt Green Covered Bond Framework, Oslo. https://www.ir.dnb.no/sites/ default/files/DNB Green Covered Bond Framework_Sep 2020.pdf. (downloaded: 22.01.2021).

Dobránszky-Bartus, K. - Krenchel, J. V. (2020): The EU sustainable finance taxonomy regulation: the first regulatory definition of what constitutes sustainable economic activity. Economy and Finance, 7(4), 386-411,

https://doi.org/10.33908/EF.2020.4.2.

DZHYP (2020): The German Pfandbrief Market 2020 | 2021, Hamburg. https://dzhyp.de/fileadmin/ user_upload/Dokumente/Ueber_uns/Marktberichte/DZHYP_Pfandbriefmarkt_2020_EN.pdf (downloaded: 15.01.2021).

ECBC (2021): Covered Bond Frameworks. Available at http://www.ecbc.eu/framework/list (downloaded: 06.01.2021).

EU (2020): Regulation (EU) 2020/852 of the European Parliament and of the Council, European Union.

EU (2021): EU Green Bond Standard. https://ec.europa.eu/info/business-economy-euro/bankingand-finance/sustainable-finance/eu-green-bond-standard_en (downloaded: 06.01.2021).

Harrison, C. - Partridge, C. - Tripathy, A. (2020): What's in a Greenium: An Analysis of Pricing Methodologies and Discourse in the Green Bond Market. The Journal of Environmental Investing 10(1), 64-75.

HAY, J. 2020. Taxonomy in trouble. GlobalCapital. https://www.globalcapital.com/article/ biplj7vwd5otrh/taxonomy-in-trouble (downloaded: 09.01.2021).

Hoyer, W. (2017): CAB Newsletter 10 th anniversary (June). https://www.eib.org/attachments/fi/2017cab-newsletter-10years.pdf (downloaded: 02.01.2021).

ICMA (2018): Green Bond Principles, Paris. https://www.icmagroup.org/green-social-and-sustainability-bonds/green-bond-principles-gbp/ (downloaded: 17.12.2020).

EPC (2019): Directive (EU) 2019/2162 of the European Parliament and of the Council of 27 November 2019 on the issue of covered bonds and covered bond public supervision and amending Direc- 
tives 2009/65/EC and 2014/59/EU. https://eur-lex.europa.eu/legal-content/EN/TXT/HTML/?ur $\mathrm{i}=\mathrm{CELEX}: 32019 \mathrm{~L} 2162 \&$ qid $=1614683178253$ \& from $=\mathrm{EN}$.

ISS-ESG (2020): Re-verification of the Sustainability Quality of the Issuer and Green Bond Asset Pool (Berlin Hyp AG), Rockville. https://www.isscorporatesolutions.com/file/documents/spo/ spo-berlinhyp-20200424.pdf (downloaded:15.01.2021).

Jht. (1997): 1997. évi XXX. törvény a jelzálog-hitelintézetről és a jelzáloglevélről [Act XXX of 1997 on Mortgage Loan Companies and on Mortgage Bonds].

Jones, L. (2020): \$1Trillion Mark Reached in Global Cumulative Green Issuance: Climate Bonds Data Intelligence Reports: Latest Figures. climatebonds.net. https:/climatebonds. net/2020/12/1trillion-mark-reached-global-cumulative-green-issuance-climate-bonds-dataintelligence (downloaded: 28.12.2020).

KIDNEY, S. (2015): The review: first ever green covered bond (Pfandbrief) issued by German giant BerlinHyp - EUR50om, 7yr, 0.125\%, AAA and 4x oversubscribed! Wunderbar! climatebonds. net. https://www.climatebonds.net/2015/05/review-first-ever-green-covered-bond-pfandbriefissued-german-giant-berlinhyp-eur5oom-7yr (downloaded: 27.12.2020).

Kremer, C. - Prinz, U. - Westendorf, H. (2018): Luxembourg goes "green" - introduction of a new Luxembourg renewable energy covered bond regime, Luxembourg. https://www.cliffordchance. com/content/dam/cliffordchance/briefings/2018/o7/luxembourg-goes-green-introduction-of-anew-luxembourg-renewable-energy-covered-bond-regime.pdf (downloaded: 05.01.2021).

Kullig, S. et al. [eds.] (2020): ECBC European Covered Bond Factbook 2020 15th ed., Bruss: European Mortgage Federation - European Covered Bond Council (EMF-ECBC).

Kunze, F. (2021): Komerční Banka, NORD/LB Issuer View, Hanover.

LARCKer, D. F. - WatTs, E. M. (2020): Where's the greenium? Journal of Accounting and Economics, Elsevier, 69(2). https://doi.org/10.1016/j.jacceco.2020.101312.

LARsON, F. (2018): The Greenium. Uppsala University.

LAU, P. et al. (2020): The economics of the greenium: How much is the World willing to pay to save the Earth?, Hong Kong.

LU (2018): Law of 22 June 2018 amending the Law of 5 April 1993 on the financial sector, as amended, with respect to the introduction of renewable energy of covered bonds, Luxembourg. https:// www.cssf.lu/wp-content/uploads/L_220618_covered-bonds_update_LFS_eng.pdf (downloaded: 05.01.2021).

Marty, D. - Hunter, B. (2020): General Principles for Assessing Environmental, Social and Governance Risks Methodology. Credit Strategy and Standards, Moody's Investors Service.

mBank (2020): mBank S. A. Group Green Bond Framework.

MinÁlovits, Z. - PAUlik, É. - TAPAszti, A. (2019): Beruházások és zöldfinanszírozás [Investments and green financing]. In ViráG, B. [ed.]: A jövő fenntartható közgazdaságtana [Sustainable economics of the future]. Budapest: Magyar Nemzeti Bank, 166-199.

MinÁlovits, Z. - TAPAszti, A. (2018): Zöldkötvény, a fenntartható fejlődést támogató pénzügyi instrumentum [Green bond, a financial instrument supporting sustainable development]. Pénzügyi Szemle (3), 312-327.

MNB (2020a): International conference on green finance: the goal is a 'green recovery' from COVID-19. MNB Sajtóközlemények. https://www.mnb.hu/en/pressroom/press-releases/pressreleases-2020/international-conference-on-green-finance-the-goal-is-a-green-recovery-fromcovid-19 (downloaded: 13.01.2021).

MNB (2020b): Megtörtént az első hazai zöld vállalatikötvény-kibocsátás az NKP keretében [The first domestic corporate bond issue in the framework of NKP]. MNB Sajtóközlemények. https:// www.mnb.hu/sajtoszoba/sajtokozlemenyek/2020-evi-sajtokozlemenyek/megtortent-az-elso- 
hazai-zold-vallalatikotveny-kibocsatas-az-nkp-kereteben (downloaded: 12.01.2021 [The National Bank of Hungary is preparing the purchase of green covered bonds]).

MNB (2020c): Zöld jelzáloglevelek vásárlását készíti elő a Magyar Nemzeti Bank. MNB Sajtóközlemények. https://www.mnb.hu/sajtoszoba/sajtokozlemenyek/202O-evi-sajtokozlemenyek/zoldjelzaloglevelek-vasarlasat-kesziti-elo-a-magyar-nemzeti-bank (downloaded: 06.01.2021).

Nagy, G. L. - Incze, Z. - Landgraf, E. (2020): Mortgage Bank Refinancing - Proposals for Implementation of the European Covered Bond Directive in Hungary. Financial and Economic Review 19(3), 102-129. https://en-hitelintezetiszemle.mnb.hu/letoltes/fer-19-3-st4-nagy-inczelandgraf.pdf.

NORD/LB (2020): NORD/LB CBB successfully issues green covered bond on the capital market for the first time. Press Release. https://www.nordlb.com/nordlb/press/press-release/nordlb-cbbsuccessfully-issues-green-covered-bond-on-the-capital-market-for-the-first-time/ (downloaded: 07.01.2021).

oekom (2014):Verification of the sustainability quality of Münchener Hypothekenbank eG's first ESG Pfandbrief, Munich. https://www.isscorporatesolutions.com/file/documents/spo/spomuhypo-2014.pdf (downloaded: 21.01.2021).

oekom (2015): Verification of the sustainability quality of the inaugural Green Pfandbrief issued by Berlin Hyp AG, München. https://www.isscorporatesolutions.com/file/documents/spo/spoberlinhyp-1apr2015.pdf (downloaded: 21.01.2021).

OPMB (2020): OP Mortgage Bank Green Covered Bond Framework, Helsinki. https://www.op.fi/ documents/20556/30424959/OPMB+Green+Covered+Bond+Framework+2020/d90986db-dff2b75b-5fa7-f8af888fc6b4 (downloaded: 21.01.2021).

PARTRIDGe, C. C. (2019): Green Municipal Bonds and the Financing of Green Infrastructure in the United States. University College London.

Partridge, C. C. - Medda, F. R. (2018): Green Premium in the Primary and Secondary US Municipal Bond Markets. SSRN Electronic Journal, 1-20. https://dx.doi.org/10.2139/ssrn.3237032.

PKOBH, 2019. PKO Bank Hipoteczny SA Green Covered Bond Framework. https://www.pkobh.pl/ media_files/99oa4a78-d1b4-4c85-bo2f-8c51024e1204.pdf (downloaded: 21.01.2021).

Preclaw, R. - Bakshi, A. (2015): The Cost of Being Green. Credit Research, Barclays.

S\&P (2019a): Incorporating Sovereign Risk In Rating Structured Finance Securities: Methodology And Assumptions. https://www.capitaliq.com/CIQDotNet/CreditResearch/RenderArticle.asp $\mathrm{x}$ ?articleId $=2159636 \&$ Sct ArtId $=472295 \&$ from $=$ CM\&nsl_code $=$ LIME\&sourceObjectId $=1083696$ 4\&sourceRevId=2\&fee_ind=N\&exp_date=20290605-17:34:26 (downloaded: 13.01.2021).

S\&P (2019b): The Role Of Environmental, Social, And Governance Credit Factors In Our Ratings Analysis. https://www.spglobal.com/ratings/en/research/articles/190912-the-role-of-environmental-social-and-governance-credit-factors-in-our-ratings-analysis-11135920\#: :text=Key Takeaways,rating outlooks\% $2 \mathrm{C}$ and ratings headroom (downloaded: 17.01.2021).

S\&P, 2018. What's Behind The Rise In Green Covered Bond Issuance? Credit FAQ, S\&P Global Ratings, London.

Schuller, M. - Melms, M. - Berninger, R. (2020): The different dimensions of sustainable covered bonds. In Kullig, S. et al. [eds.]: ECBC European Covered Bond Factbook 2020. Brussels, Belgium: European Mortgage Federation - European Covered Bond Council (EMF-ECBC), 69-81.

SCHÜтZE, F. (2020): Transition risks and opportunities in residential mortgages, Berlin. https://www. diw.de/documents/publikationen/73/diw_01.c.802032.de/dp1910.pdf (downloaded: 17.12.2020), https://dx.doi.org/10.2139/ssrn.3726o12.

Stöcker, O. - Costa, C., 2020. Overview of Covered Bonds. In Kullig, S. et al. [eds.]: ECBC European Covered Bond Factbook 2020. Brussels, Belgium: European Mortgage Federation - European Covered Bond Council (EMF-ECBC), 143-150. 
sustainabonds.com (2014): MünchenerHyp ESG covered bond first uncovers new buyers. https:// sustainabonds.com/munchenerhyp-esg-covered-bond-first-uncovers-new-buyers/ (downloaded: 27.12 .2020$)$.

Sustainalytics (2020a): Second-Party Opinion DNB Boligkreditt Green Covered Bond Framework, Amsterdam. https://www.ir.dnb.no/sites/default/files/DNB Boligkreditt Green Covered Bond Framework Second-Party Opinion_o.pdf. (downloaded: 23.01.2021).

Sustainalytics (2020b): Second-Party Opinion mBank S.A. Group Green Bond Framework, Amsterdam. https://www.mhipoteczny.pl/download/relacje-inwestorskie/mbank-green-bond-framework-second-party-opinion-002.pdf (downloaded: 23.01.2021).

Sustainalytics (2019a): Second-Party Opinion NORD / LB CBB "Lettres de Gage Renewable Energy" Green Bond Framework, Amsterdam. https://www.nordlb.lu/page/docManager/docs/578/ NORDLB CBB Green Bond Framework Second Party Opinion Sustainalytics.pdf (downloaded: 2021.01.23.).

Sustainalytics (2020c): Second-Party Opinion Nykredit Green Bond Framework, Amsterdam. https://www.nykredit.com/siteassets/ir/files/debt/green-bonds/second-party-opinion-nykreditgreen-bond-framework-2020_2020-11-04.pdf (downloaded: 23.01.2021).

Sustainalytics (2019b): Second-Party Opinion PKO Bank Hipoteczny SA Green Covered Bond, Amsterdam. https://www.pkobh.pl/media_files/43702398-eae5-4456-a34b-9d12bf2b1d23.pdf (downloaded: 23.01.2021).

VDP (2019): Minimum standards for the use of wordmarks "Green Pfandbrief"/“Grüne Pfandbrief" (for Mortgage Pfandbriefe), Berlin. https://www.pfandbrief.de/site/dam/jcr:4b2oof2e8dd7-49d5-ab84-d89144d37164/201908_vdp_mindeststandards_GPB_EN.pdf (downloaded: 07.01.2021).

WensaAs, E. - Wist, J. B. (2019): Greenium or myth. Norwegian School of Economics.

Zeidler, A. - Bredholt, C. (2018): Announcement: Moody's: Luxembourg's covered bond legal framework offers dual recourse credit strength for renewable energy funding, London. https:// www.moodys.com/research/Moodys-Luxembourgs-covered-bond-legal-framework-offers-dual-recourse-credit--PR_388908 (downloaded: 13.01.2021).

Zerbib, O.D. (2017): The Green Bond Premium. https://www.iae-paris.com/sites/default/files/2_FINAGRI\%20David\%20Zerbib\%2oDec\%2017_o.pdf. 